Journal of Extension Education

Vol. 29 No. 1, 2017

DOI:https: / / doi.org/10.26725/JEE.2017.1.29.5797-5805

\title{
Stakeholder Analysis for Farmer inclusive Value chain Development in Mango
}

\author{
K. Nadhika ${ }^{1}$ and Jayasree Krishnankutty ${ }^{2}$
}

\begin{abstract}
Mango is being cultivated over a substantial area in Palakkad District of Kerala state. Being one of the significant agricultural commodity value chains existing in Kerala, the mango value chain of Palakkad district needs urgent attention to improve its performance. The study highlights the stakeholder analysis and SWOC matrix analysis of the mango sector. Stakeholders were asked to identify the strengths, weaknesses, opportunities and challenges in the mango sector. Based on the highest score obtained, four strategic options viz., enhancing value addition and product development, promotion of branding, educating the farmers on building competitiveness and increasing export potential by addressing quality parameters were identified.
\end{abstract}

Keywords : Value chain; Stakeholders; SWOC analysis; Strategic options; Mango; Kerala

\section{INTRODUCTION}

Mango is cultivated over a substantial area in Palakkad District of Kerala State and is being exported to a number of countries, the remaining is being sold in domestic markets. In a rural area like Palakkad, mango industry plays a vital role in bringing about a revolution in cultivation practices and also in the lives of mango cultivators. Muthalamada is one of the biggest centre of mango production in South India.

The mango orchards in Muthalamada cover around 45,000 hectares, with about 5000 mango cultivators. The annual production of mango in Muthalamada Panchayat is approximately 40,000 tons. The mangoes from Muthalamada are famous for their flavor, taste and juiciness. However, the mango sector in Palakkad district is not devoid of any problems. Radha $\&$ Nair (2000) had identified ignorance of the growers about the real price of their produce and lack of marketing facilities which result in interference of middle men, as the major problems in mango sector in Palakkad District.

Being one of the few substantial agricultural commodity value chains existing in Kerala, which provides hope for

1.PG Scholar and 2- Professor, Department of Agricultural Extension, College of Horticulture, Kerala Agricultural University, Vellanikkara-680 656, Thrissur, Kerala 
the small holder farmers, the mango value chain of Palakkad district needs urgent attention to improve its performance.The current paper discusses the stakeholder analysis and SWOC matrix analysis done as part of the study which contributed to formation of strategic options to strengthen the value chain in favour of farmers.

\section{METHODOLOGY}

The present study was conducted using exploratory research design. Muthalamada panchayat in Palakkad district of Kerala was selected as the location of the study as it had the largest area under mango cultivation. The sample consisted of 60 farmers selected through random sampling. Thirty respondents were also chosen separately representing other stakeholder groups in the value chain through random sampling and snowballing technique. Primary data collection was carried out using pre tested structured interview schedule by conducting group discussions and interviews.

\section{Stakeholder Analysis}

Stakeholder analysis is the identification of the key stakeholders, an assessment of their interests, and the ways in which these interests affect project riskiness and viability. Stakeholder analysis contributes to project design through the logical framework and by helping to identify appropriate forms of stakeholder participation.

\section{Procedure}

Inventory of stakeholders was formed after key informant interviews, referring secondary sources and also consultation with experts. The interests of each stakeholder were identified in relation to the problems being addressed by a project and its objectives. The relative priority which the project should give to each stakeholder was to be worked out. Assessment of importance and influence of each group of the stakeholders was done using perceptions by key stakeholders. By combining influence and importance, a total score was obtained and the stakeholders were arranged in descending order of their scores (DFID, 1995).

\section{SwOC Analysis}

The stakeholders comprising growers, collection agents, development personnel, land owners and input suppliers were requested to point out the strengths, weaknesses, opportunities and challenges of the mango sector in Muthalamada (Vermeulen et al., 2008).

The strengths theoretically denote the Internal Positive Factors (IPFs), weaknesses denote the Internal Negative Factors (INFs), opportunities denote the External Positive Factors (EPFs) and the challenges denote the External Negative Factors (ENFs).

\section{Steps in SWOC Analysis}

1. The strengths, weaknesses, opportunities and challenges were recorded 
2. The weaknesses were rephrased in a positive tone without losing the central idea

3. The strategic options were formulated from these positive statements and represented in a horizontal manner

4. The strengths (positives) and challenges (negatives) were given in the vertical axis

5. Based on consultation with the experts, scores were given by comparing the strategic options with the treatments

6. Subtotal of both the scores obtained from positive statements (ST1) and negative statements (ST2) in comparison with the strategic options were calculated

7. Balance score was obtained by subtracting the subtotal of negative statements (ST2) from the subtotal of positive statements (ST1)

8. The strategic options having the highest scores were selected

\section{FINDINGS AND DISCUSSION}

\section{Stakeholders and their Role in Mango} Value Chain

The major stakeholders and their functions in the mango value chain of Muthalamada were identified through key informant interviews and group discussions. Table 1 lists out the stakeholders and their respective functions.

Table 1.

Stakeholders and their Role in Mango Value Chain

\begin{tabular}{|c|l|l|}
\hline S1.No. & Stakeholders & \multicolumn{1}{c|}{ Role / Function } \\
\hline 1 & Nursery developers & Provide good quality planting materials to the farmers \\
\hline 2 & Input suppliers & $\begin{array}{l}\text { Supply inputs such as fertilizers, pesticides, machinery, } \\
\text { etc. }\end{array}$ \\
\hline 4 & Land owners & $\begin{array}{l}\text { They can be either the orchard owners, leased } \\
\text { contractors, farmer cum merchants who are involved } \\
\text { in cultivation activities }\end{array}$ \\
\hline 5 & $\begin{array}{l}\text { Pre-harvest } \\
\text { contractor }\end{array}$ & $\begin{array}{l}\text { Owners of the orchard who lease out the land on } \\
\text { contract basis for a particular period of time. They } \\
\text { are unaware about the marketing of the produce from } \\
\text { their orchard }\end{array}$ \\
\hline
\end{tabular}




\begin{tabular}{|c|c|c|}
\hline S1.No. & Stakeholders & Role / Function \\
\hline 6 & Collection agent & $\begin{array}{l}\text { They own individual collection units or sheds. } \\
\text { They procure mangoes directly from the producers. } \\
\text { Sometimes, they are farmers themselves, and they } \\
\text { market their produce through their shed along with } \\
\text { the produce of other farmers }\end{array}$ \\
\hline 7 & Traders & $\begin{array}{l}\text { They are large merchants from other states, especially } \\
\text { North India. They procure mangoes either directly from } \\
\text { large farmers or through the collectors and distribute } \\
\text { to the distant market suppliers }\end{array}$ \\
\hline 8 & Mandiwalas & $\begin{array}{l}\text { Mandiwalas are the wholesalers who collect the } \\
\text { produce from the traders at the terminal market and } \\
\text { supply the produce to retailers and processors }\end{array}$ \\
\hline 9 & Retailers & $\begin{array}{l}\text { They are the fruit stall owners, roadside vendors and } \\
\text { supermarkets from where the consumers buy the } \\
\text { products. They may sell the produce as such or after } \\
\text { value addition and processing }\end{array}$ \\
\hline 10 & Processors & $\begin{array}{l}\text { They convert the raw product into value added } \\
\text { products such as pulp, jams, jellies, juice, pickle and } \\
\text { other canned products }\end{array}$ \\
\hline 11 & Exporters & $\begin{array}{l}\text { Exporters are involved in international trade. They } \\
\text { supply high quality fruits to other countries by taking } \\
\text { into account their quality implications }\end{array}$ \\
\hline 12 & Consumers & $\begin{array}{l}\text { They are the end users from within the locality to other } \\
\text { country. With change in the area, the preference of the } \\
\text { consumer also changes. In India, less fibrous sweet } \\
\text { fleshy mangoes are mostly preferred }\end{array}$ \\
\hline 13 & $\begin{array}{l}\text { Development } \\
\text { personnel }\end{array}$ & $\begin{array}{l}\text { They are extension workers of institutions such as } \\
\text { KrishiBhavan, research stations, University, etc. who } \\
\text { provide services to the farmers and other stakeholders }\end{array}$ \\
\hline 14 & Local body members & $\begin{array}{l}\text { They are mainly involved in political and organizational } \\
\text { activities wherein policies regarding various aspects of } \\
\text { value chain are formulated by them }\end{array}$ \\
\hline
\end{tabular}


Interdependencies among the Stakeholders

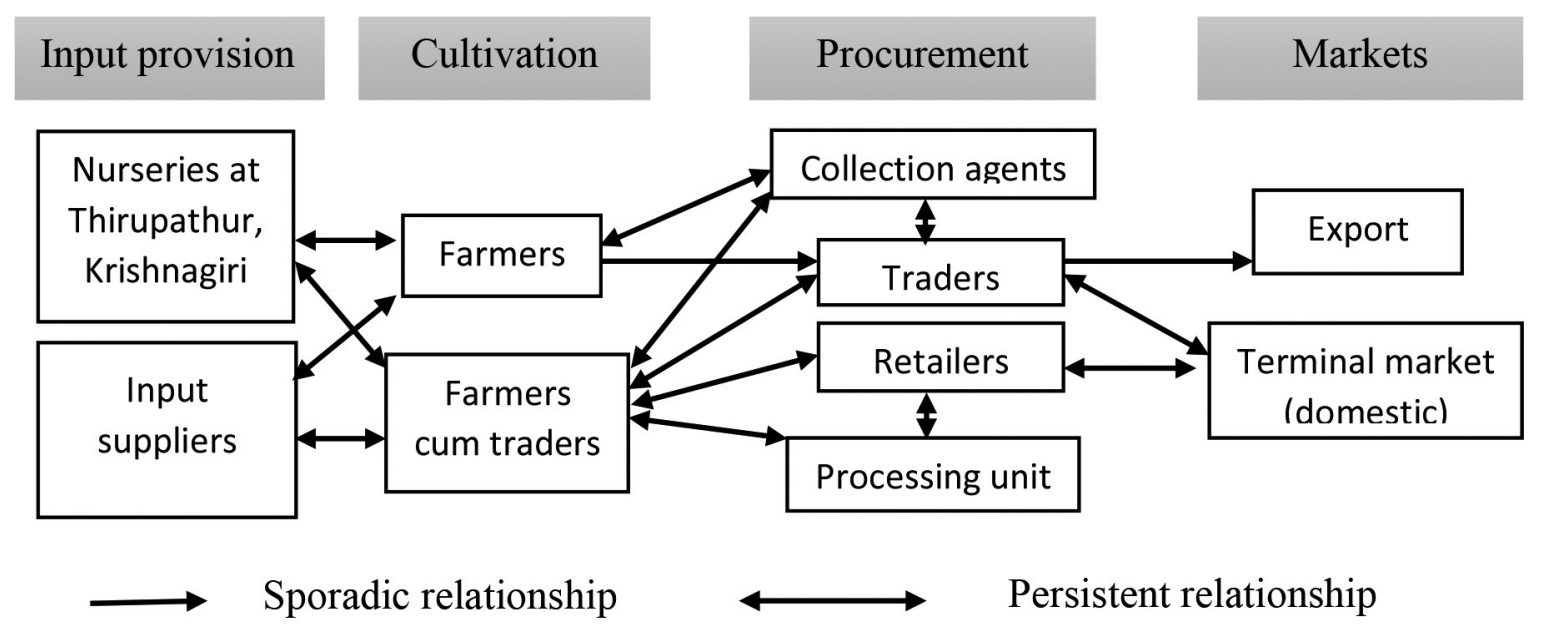

Fig. 1: Relationship and Linkage among the Stakeholders

In case of input provision, the farmers and farmers cum traders showed a persistent relationship with both nursery developers and input suppliers. In the procurement stage, the farmers cum traders had more persistent relationship with the traders, retailers and processors when compared to ordinary farmers as they themselves act as the collection agent and directly market the produce to these actors. The ordinary farmer maintains only a sporadic relationship with traders, retailers and processors but they have a persistent relationship with the collection agent/ farmer cum trader. In the case of terminal market, the traders and retailers had a persistent relationship with the domestic terminal market and the collection agent and processors depended on the traders and retailers to market the produce. The traders had only sporadic relationship with the exporters.

Table 2.

Stakeholder Analysis: Importance-Influence Ranking

\begin{tabular}{|c|l|c|c|c|}
\hline S1. No. & \multicolumn{1}{|c|}{ Stakeholder } & Importance & Influence & Total \\
\hline 1 & Nursery developers & 13 & 14 & 27 \\
\hline 2 & Input suppliers & 6 & 12 & 18 \\
\hline 3 & Growers & 1 & 13 & 14 \\
\hline 4 & Landowners & 11 & 11 & 22 \\
\hline 5 & Pre-harvest contractor & 7 & 7 & 14 \\
\hline 6 & Collection agents & 5 & 6 & 11 \\
\hline
\end{tabular}


Stakeholder Analysis for Farmer inclusive Value chain Development in Mango

\begin{tabular}{|c|l|c|c|c|}
\hline S1. No. & \multicolumn{1}{|c|}{ Stakeholder } & Importance & Influence & Total \\
\hline 7 & Traders & 4 & 2 & 6 \\
\hline 8 & Processors & 8 & 5 & 13 \\
\hline 9 & Retailers & 9 & 4 & 13 \\
\hline 10 & Mandiwalas & 2 & 1 & 3 \\
\hline 11 & Exporters & 10 & 3 & 13 \\
\hline 12 & Consumers & 3 & 10 & 13 \\
\hline 13 & Development personnel & 12 & 9 & 21 \\
\hline 14 & Local body members & 14 & 8 & 22 \\
\hline
\end{tabular}

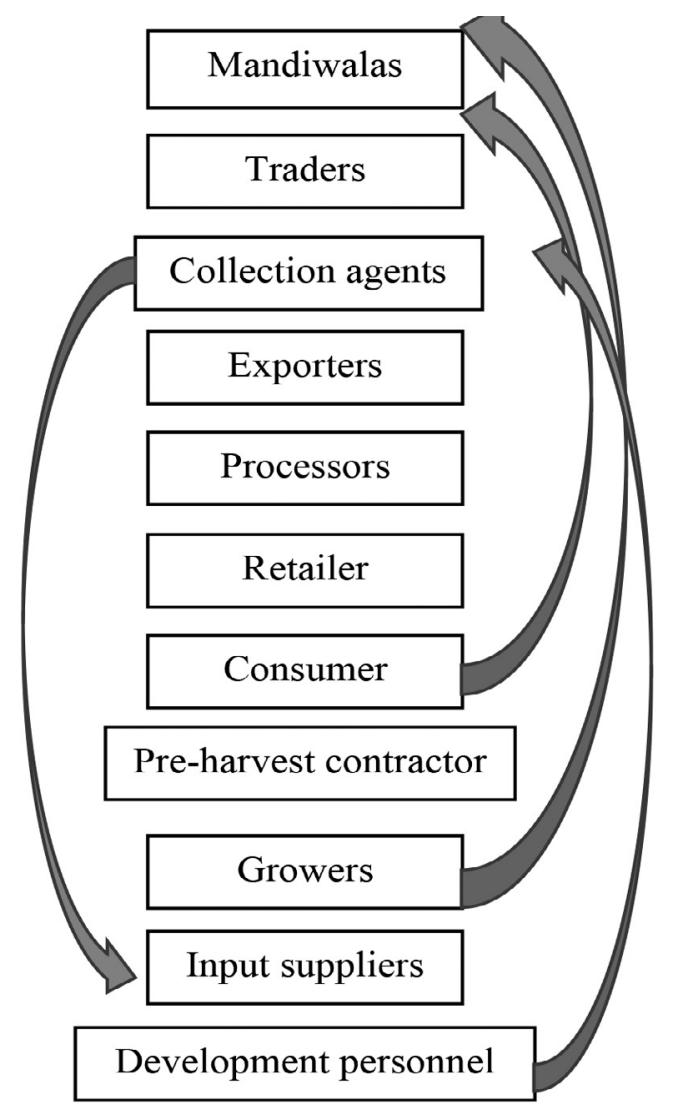

Land owners

Local body member

Nursery developers

(a)

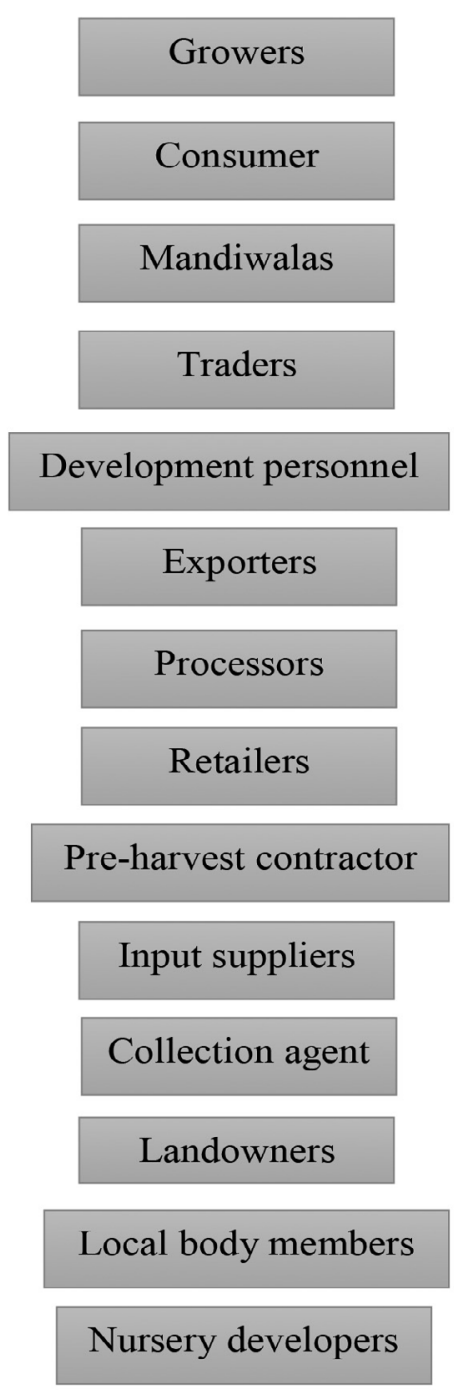

(b)

Fig.2 : Arrangement of Stakeholders based on the Total Score 


\section{Stakeholder Analysis}

Table 2 shows the stakeholder inventory in which ranks were assigned to stakeholders based on their importance and influence and final score was obtained by adding the two. According to the scores obtained, the stakeholders are arranged in descending order in Fig. 2 (a). It was observed that the intermediaries like mandiwalas, traders and collection agents were dominating the value chain. Fig. 2 (b) shows the rearrangement of stakeholders according to the importance that should be given to each stakeholders for farmer inclusiveness wherein the growers, consumers and development personnel were given higher position in the value chain. The intermediaries like collection agents and pre-harvest contractors were given much lower position in the value chain.

\section{SWOC analysis}

The respondents identified opportunities and challenges in the mango value chain of Muthalamada.

\section{Strengths (Internal positive factors)}

1. Large area under cultivation

2. Commercialization

3. Long term investment

4. High density planting

5. Diversity in mango varieties

6. Availability of technical support

7. Capture early market

Weaknesses (Internal negative factors)

1. Labor shortage

2. High cost of labor

3. High input usage

4. Perishability

5. Lack of infrastructure facility

6. Ignorance of the farmers
7. Harvesting loss

8. Lack of funding

9. Improper management practices

\section{Opportunities (External positive factors)}

1. Export potential

2. Processing demand

3. Large scale market demand

4. Related industries

5. Job opportunities

6. Large number of markets

7. Branding of the produce

8. Involvement of women and youth

9. Ecological benefits

10. Investment from MNCs

Challenges (External negative factors)

1. Unexpected change in climatic condition

2. Lack of market information

3. Price fluctuation

4. Incidence of pest and diseases

5. Change in consumer preference

6. Political intervention

7. Lack of policies for mango sector

8. Lack of research

By subtracting the subtotal of negative statements (ST2) from the subtotal of positive statements (ST1), strategic options were obtained (Table 3 ) and the strategic options having the highest value were selected as the best strategic options.

The strategic options derived from SWOC analysis were enhancing value addition and product development, promoting branding of the produce, educating the farmers on building competitiveness, increasing export potential by addressing quality parameters. 
Stakeholder Analysis for Farmer inclusive Value chain Development in Mango

\begin{tabular}{|c|c|c|c|c|c|c|c|c|c|c|c|c|c|c|c|c|}
\hline 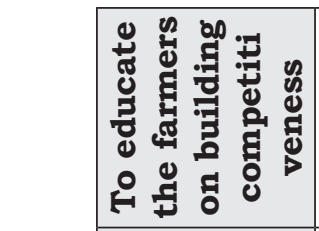 & $\sim$ & $\nabla$ & $M$ & L & $\sigma$ & 10 & $\nabla$ & $\stackrel{\widehat{N}}{ }$ & $\neg$ & $\nabla$ & $\nabla$ & $\infty$ & $\neg$ & $\nabla$ & N & 음 \\
\hline 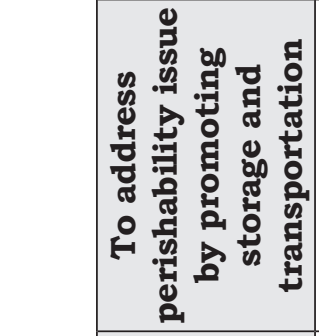 & N & $\mathrm{N}$ & $m$ & $\mathrm{~N}$ & $\sigma$ & 10 & $\nabla$ & $\stackrel{\sim}{\curvearrowright}$ & $\nabla$ & $\neg$ & $\nabla$ & $\sim$ & - & $\nabla$ & $\begin{array}{l}0 \\
-1\end{array}$ & 0 \\
\hline 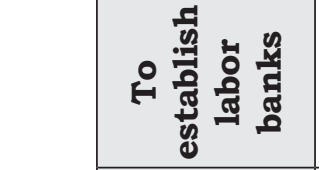 & N & $m$ & M & $\neg$ & $\neg$ & D & $\sim$ & $\stackrel{20}{\longrightarrow}$ & $\neg$ & $\neg$ & -1 & N & $\mathrm{N}$ & - & $\infty$ & $\Lambda$ \\
\hline 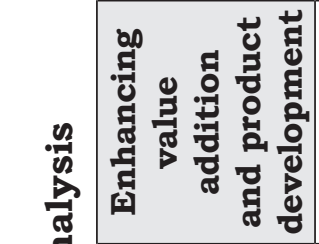 & N & $\nabla$ & $\sigma$ & $\sigma$ & 10 & 10 & $m$ & $\hat{\sim}$ & $\neg$ & N & $m$ & $m$ & $\neg$ & $\sim$ & N & 10 \\
\hline 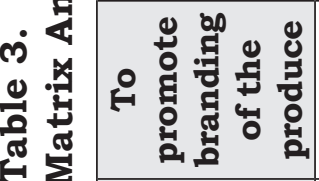 & $m$ & 1 & ナ & N & + & + & $n$ & $\stackrel{\widehat{N}}{\sim}$ & $\neg$ & N & $\forall$ & $\infty$ & N & $\mathrm{N}$ & 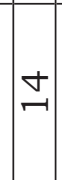 & $m$ \\
\hline 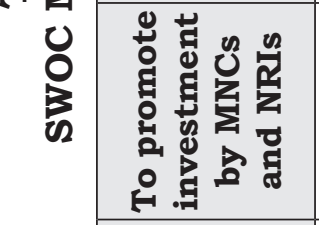 & $\sigma$ & م & م & $N$ & $m$ & N & $\nabla$ & $\stackrel{\sim}{\mathrm{N}}$ & $\sim$ & $\sim$ & $m$ & 10 & $m$ & $m$ & $\underset{\infty}{\infty}$ & $\wedge$ \\
\hline 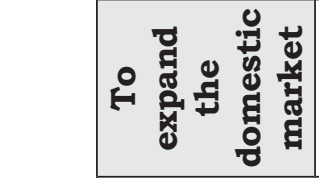 & م & $\sigma$ & $m$ & $N$ & $m$ & $m$ & $m$ & 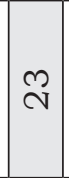 & $\nabla$ & 10 & 10 & $m$ & $m$ & $n$ & 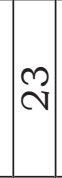 & 0 \\
\hline 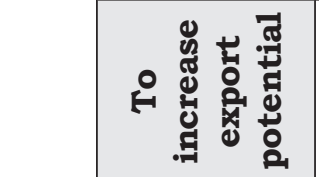 & م & م & 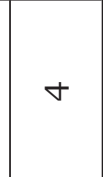 & $\sigma$ & $\sigma$ & ח & N & $\stackrel{\curvearrowright}{\mathrm{N}}$ & 10 & 10 & $\forall$ & $m$ & N & $n$ & $\stackrel{\mathrm{N}}{\mathrm{N}}$ & $\Lambda$ \\
\hline $\begin{array}{l}8 \\
8 \\
0 \\
0\end{array}$ & 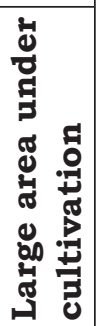 & 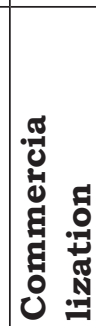 & 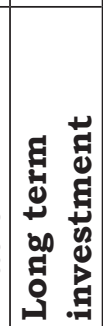 & 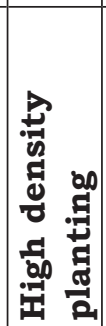 & 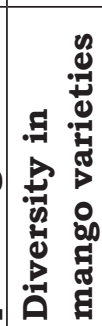 & 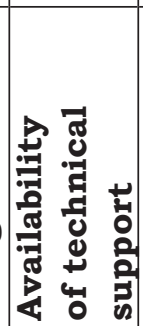 & 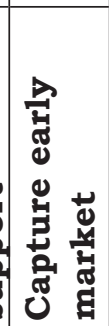 & 昆 & 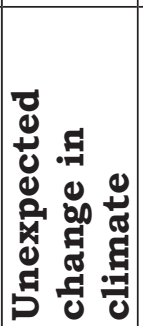 & 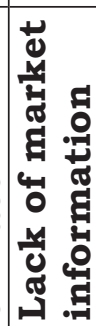 & 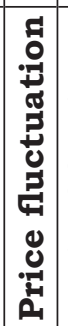 & 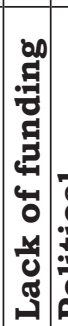 & 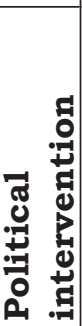 & 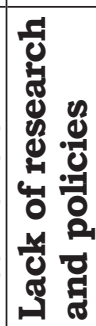 & : & 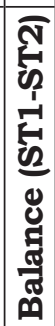 \\
\hline घं & -1 & N & M & $\nabla$ & in & 0 & $\wedge$ & & -1 & N & m & $\theta$ & 10 & $\bullet$ & & \\
\hline
\end{tabular}




\section{CONCLUSION}

The mango sector in Muthalamada is highly competitive as it captures the early markets all over the world.The high demand for mangoes in the Arabian countries is a key factor that keeps this sector thriving and dynamic. Among the stakeholders currently the collection agents, traders and mandiwalas were seen to dominate the scenario. But for farmer inclusive development of value chain, the growers, consumers and development personnel should be able to influence the chain more. The study has shown that the strategic options of enhancing value addition and product development, promoting branding of the produce, educating the farmers on building competitiveness and increasing export potential by addressing quality parameters are potential ways in which this can be achieved. These deductions will apply to the mango sector in Kerala in general. It is one of the few sectors in agriculture that keeps the farmer benefitted. Hence, every effort should be taken for its sustainable development in line with the findings of the study.

\section{REFERENCES}

DFID [Department for International Development]. (1995). Guidance note on how to do stakeholder analysis of aid projects and programmes. Retrieved from: https:// beamexchange.org/uploads / filer_ public/5d/4c/5d4c7b02-a 25d43ab-ae33-0e4811b7c5fb/guidance_ stakeholderanalysis.pdf.

Jayarajan, M.R. (2011). Biodiversity analysis of traditional mango types of Kerala and studies on the reproductive biology of selected popular types. Unpublished M.Sc. (Hort.) thesis, Kerala Agricultural University, Thrissur, 89p.

Mannambeth, R., Parameswaran, N.K.,Rajeevan, P.K., Zucker, J., \& Sthapit, B. (2015). A preliminary appraisal of mango biodiversity in Kerala, India. Indian Journal of Plant Genetic Resource, 28(1), 62-71.

Radha, T \& Nair, S.R. (2000). Status of mango cultivation in Kerala. ActaHorticultrae, 509, pp.117-121.

Vermeulen, S., Woodhill, J., Proctor, F., \& Delnoye, R. (2008). ChainWide Learning for Inclusive Agrifood Market Development: A guide to multistakeholder processes for linking smallscale producers to modern markets. International Institute for Environment and Development, UK and Wageningen University and Research Centre, Wageningen, Netherlands, 5.86- 5.87.

Vignesh, G. \& Santhiya, R. (2014). A study on difficulties in growing and marketing mango (with special reference to Palakkad district). Intercontinental Journal of Marketing Management, 2(2), 141-148. 